\title{
Uji Kombinasi Trichoderma dan Kompos terhadap Pembentukan Bintil Akar dan Produksi Tanaman Kacang Tanah (Arachis hypogaea L.)
}

\author{
Baso Amir dan Satria Dermawan ${ }^{\mathrm{b}}$ \\ ${ }^{a}$ Fakultas Pertanian, Universitas Cokroaminoto Palopo, Palopo, Sul-Sel, Indonesia, email: baso.amt@gmail.com \\ ${ }^{b}$ Fakultas Pertanian, Universitas Cokroaminoto Palopo, Palopo, Sul-Sel, Indonesia, email: darma.str@yahoo.com
}

\section{Article Info}

\section{Article history:}

Received 26 September 2019

Received in revised form 04 Oktober 2019

Accepted 16 Oktober 2019

DOI:

https://doi.org/10.32938/sc.v4i02.834

Keywords:

Bintil akar

Trichoderma

Kompos

Produksi

\section{Abstrak}

Pemberian Trichoderma dan kompos merupakan salah satu cara untuk memaksimalkan fungsi perakaran dan ketersediaan hara untuk dapat diserap oleh tanaman sehingga mempengaruhi pertumbuhan dan hasil tanaman. Penelitian ini bertujuan untuk mengetahui pengaruh pemberian trichoderma dan kompos terhadap pembentukan bintil akar dan hasil tanaman kacang tanah. Penelitian menggunakan metode Rancangan Acak Kelompok (RAK) yang terdiri dari 6 perlakuan yang diulang sebanyak 4 kali, sehingga terdapat 24unit percobaan. Perlakuan terdiri dari P0: kontrol (tanpa Trichoderma dan kompos); P1: Ttrichoderma 40 gram $+1 \mathrm{~kg}$ kompos; P2: Trichoderma 60 gram +1 kg kompos; P3: Trichoderma 80 gram +1 kg kompos; P4: Trichoderma 100 gram +1 kg kompos; P5: Trichoderma 120 gram $+1 \mathrm{~kg}$ kompos. Parameter yang diamati yaitu jumlah bintil akar, jumlah bintil akar aktif, jumlah bintil akar tidak aktif, jumlah polong per tanaman, bobot polong per tanaman, jumlah polong hampa, jumlah polong isi, dan jumlah biji per polong per tanaman. Data hasil pengamatan dianalisis dengan menggunakan software SAS. Analisis dengan menggunakan analisis varian (Anova) pada taraf $5 \%$. Apabila hasil analisis varian menunjukkan adanya beda nyata antar perlakuan, analisis dilanjutkan dengan uji jarak ganda Duncan Multiple Range Test (DMRT). Hasil penelitian menunjukkan bahwa pemberian Trichoderma dan kompos dengan dosis yang paling tinggi (P5: trichoderma 120 gram +1 kg kompos) diantara semua perlakuan terbaik pada jumlah bintil akar. Sementara dosis yang terendah P1 (Trichoderma 40 gram +1 kg kompos) memberikan hasil tertinggi untuk komponen produksi (jumlah polong per tanaman, bobot polong per tanaman, jumlah polong isi dan jumlah biji per polong per tanaman).

\section{Pendahuluan}

Kacang tanah (Arachis hypogaea L.) merupakan salah satu jenis tanaman

legum yang berpotensi untuk dikembangkan karena merupakan salah satu komoditas palawija yang memiliki manfaat sebagai sumber protein nabati yang murah dan dapat terjangkau oleh masyarakat. Hal ini menjadi salah satu alasan untuk mempertahankan dan meningkatkan produksi kacang tanah agar selalu tersedia untuk memenuhi kebutuhan masyarakat. Selain itu, kacang tanah juga memiliki nilai ekonomi yang tinggi sehingga peluang pasar dalam maupun luar negeri juga cukup besar. Produksi kacang tanah di Sulawesi Selatan dalam kurun waktu 5 (lima) tahun terakhir mengalami fluktuasi. Pada tahun 2013 produksi kacang tanah sebanyak 28.408 ton dan mengalami peningkatan pada tahun 2014 yaitu mencapai 34.464 ton. Peningkatan ini diiringi juga dengan peningkatan luas panen. Luas panen pada tahun 2013 hanya 18.812 ha dan meningkat pada tahun 2014 yaitu 24.459 ha. Namun produksi kembali menurun pada tahun 2015 dengan angka produksi sebesar 19.204 ton seiring dengan berkurangnya luas panen yaitu 19.203 ha.

Produksi kembali meningkat pada tahun 2016 mencapai 29.403 ton namun terjadi penurunan sebesar $45,01 \%$ pada tahun 2017 dengan produksi 16.169 ton. Penurunan ini juga diiringi dengan berkurangnya luas lahan sebesar 43,64\%. Luas lahan pada tahun 2016 yaitu 20.302 ha sementara di tahun 2017 hanya 11.444 ha (BPS Sulawesi Selatan, 2018). Hal ini menunjukkan bahwa penurunan luas lahan juga mempengaruhi menurunnya produksi kacang tanah. Diduga penurunan luas lahan dapat disebabkan karena alih fungsi lahan dari sektor pertanian ke non pertanian juga meningkat. Selain berkurangnya luas lahan, faktor kesuburan dan kualitas lahan juga menjadi faktor penting yang dapat mempengaruhi produksi. Bila perluasan lahan kurang memungkinkan untuk dilakukan, maka alternatif yang bisa dilakukan yaitu dengan menjaga dan meningkatkan kualitas dan tingkat kesuburan tanah melalui penggunaan bahanbahan organik. Salah satu penyebab permasalahan dalam meningkatkan produksi kacang tanah nasional yaitu penggunaan pupuk hayati dan organik masih rendah (Dirjen Tanaman Pangan, 2012). Untuk mengatasi masalah tersebut diperlukan upaya dalam hal meningkatkan produksi kacang tanah melalui penggunaan pupuk hayati.

Pupuk hayati merupakan zat yang mengandung mikroorganisme hidup dan jika diterapkan pada benih, permukaan tanaman atau tanah, dapat berkolonisasi dengan rhizosfer atau bagian dalam tanaman dan mendorong pertumbuhan tanaman dengan meningkatkan pasokan atau ketersediaan nutrisi utama bagi tanaman inang (Vassey, 2003). Penggunaan pupuk hayati mampu menjaga lingkungan tanah melalui fiksasi $\mathrm{N}$ pada tanah, pelarutan $\mathrm{P}$ dan kalium atau mineralisasi, pelepasan zat pengatur tumbuh tanaman, serta produksi antibiotik dan biodegradasi bahan organik (Sinha et al., 2014). Ketersediaan nutrisi bagi tanaman kacang tanah juga dipengaruhi oleh efektivitas bintil akar dalam memfiksasi N2 diudara untuk memenuhi kebutuhan unsur $\mathrm{N}$ bagi tanaman. Sehingga perlu mempertahankan lingkungan tanah yang baik. Salah satu bahan hayati yang dapat digunakan dalam hal meningkatkan produksi tanaman yaitu Trichoderma sp. Penggunaan Trichoderma sp dapat dikombinasi dengan pupuk organik seperti kompos.

Trichoderma sp. merupakan cendawan menguntungkan karena aktivitasnya sebagai anti fungal / biofungisida atau mycoparasitik jamur patogen. Keunggulan yang dimiliki Trichoderma sp diantaranya mudah untuk diaplikasikan, harganya murah, tidak menghasilkan racun (toksin), ramah lingkungan, tidak menganggu organisme lain terutama yang berada didalam tanah serta dapat meningkatkan residu di tanaman maupun di tanah (Puspita dan Nugroho, 2016). Penggunaan trichokompos juga meningkatkan berat segar tanaman sawi sebesar 14.330 gr dengan dosis 2,88 kg/plot (Ardian, 2009).
Ismayani (2017), menyatakan bahwa pemberian trichokompos $75 \mathrm{~g} / 5 \mathrm{~kg}$ tanah mampu meningkatkan tinggi bibit tanaman kelapa sawit sebesar $41.52 \mathrm{~cm}$.

\section{Metode}

Penelitian ini dilaksanakan di Lahan Percobaan Kampus 2 Fakultas Pertanian Universitas Cokroaminoto Palopo pada bulan Desember 2018 sampai bulan April 2019. Metode yang digunakan dalam penelitian ini adalah metode Rancangan Acak Kelompok (RAK) yang terdiri dari 6 perlakuan yang diulang sebanyak $4 \mathrm{kali}$, sehingga terdapat 24 unit percobaan. Adapun perlakuannya terdiri dari P0: Tanpa perlakuan (kontrol); P1: Pemberian trichoderma 40 gram + 1 kg kompos; P2: Pemberian trichoderma 60 gram + 1 kg kompos; P3: Pemberian trichoderma 80 gram +1 kg kompos; P4: Pemberian trichoderma 100 gram + 1 kg kompos; P5: Pemberian trichoderma 120 gram +1 kg kompos. Luas lahan yang digunakan yaitu luas $8 \mathrm{~m} \times 6,5 \mathrm{~m}$. Bedengan dibuat dengan tinggi $80 \mathrm{~cm}$ lebar $40 \mathrm{~cm}$, panjang $60 \mathrm{~cm}$. Benih kacang tanah yang digunakan adalah benih varietas Talam 1 .

Pemupukan dasar dilakukan setelah pengolahan lahan dengan menggunakan pupuk kompos. Pembuatan biakan Trichoderma yaitu dengan cara melakukan sterilisasi pada media beras dengan cara dikukus selama 10 menit. Setelah dilakukan sterilisasi, media beras kemudian didiamkan selama 30 menit hingga dingin. Setelah media beras siap, kemudian dilakukan pencampuran starter Trichoderma sp. dengan media beras hingga tercampur rata. Tahap terakhir yaitu penimbangan media yang tercampur sebanyak 200 gram di kantung plastik. Pupuk kompos yang digunakan pada penelitian ini adalah pupuk kompos dengan komposisi bahannya yaitu kotoran hewan ternak (sapi), dedak, arang sekam, dan Em-4 yang dicampur kemudian didiamkan selama 2 minggu. Jumlah benih yang ditanam adalah 2 biji per lubang dengan jarak tanam $30 \times 40 \mathrm{~cm}$. Pemeliharaan yang dilakukan berupa penyiraman, penggemburan tanah dan penyiangan serta pengendalian hama dan penyakit bila terdapat gejala serangan. Pengaplikasian trichoderma sp dan kompos dilakukan dengan cara membenamkan ditanah secara melingkar dengan jarak 5 $\mathrm{cm}$ dari batang tanaman saat tanaman berumur 14 hst (hari setelah tanam).

Parameter yang diamati yaitu jumlah bintil akar, jumlah bintil akar aktif, jumlah bintil akar tidak aktif, jumlah polong per tanaman, bobot polong (gr/tan), jumlah polong hampa, jumlah polong isi, jumlah biji per polong/tanaman. Data hasil pengamatan dari setiap variabel yang telah dilakukan selanjutnya dianalisis dengan menggunakan software SAS. Analisis dengan menggunakan analisis varian (Anova) pada taraf $5 \%$. Apabila hasil analisis varian menunjukkan adanya beda nyata antar perlakuan, analisis dilanjutkan dengan uji jarak ganda Duncan Multiple Range Test (DMRT)

\section{Hasil dan Pembahasan \\ 3.1 Bintil Akar}

Hasil pengamatan bintil akar pada saat panen dan analisis sidik ragam menunjukkan bahwa tidak terdapat perbedaan yang nyata diantara semua perlakuan terhadap jumlah bintil akar dan jumlah bintil akar yang aktif. Perbedaan yang nyata terdapat pada jumlah bintil akar yang tidak aktif diantara beberapa perlakuan pemberian cendawan trichoderma dan kompos (Tabel 1). Jumlah bintil akar yang paling banyak terdapat pada perlakuan P5 (120 g trichoderma $+1 \mathrm{~kg}$ kompos) walaupun tidak berbeda nyata dengan perlakuan lainnya. Jumlah bintil akar yang tidak aktif juga terdapat pada perlakuan P5, sedangkan yang lebih sedikit yaitu pada perlakuan P3 (80 g trichoderma $+1 \mathrm{~kg}$ kompos). Sementara untuk bintil akar yang aktif terdapat pada perlakuan P3 (80 $\mathrm{g}$ trichoderma $+1 \mathrm{~kg}$ kompos) tetapi juga tidak terdapat perbedaan yang nyata diantara semua perlakuan. Banyaknya jumlah bintil akar yang terbentuk pada 
perlakuan P5, diduga karena dosis pemberian Trichoderma yang termasuk paling tinggi diantara semua perlakuan.

Tabel 1. Rata-Rata Jumlah Bintil Akar, Jumlah Bintil Akar Aktif, Jumlah Bintil Akar Tidak Aktif Saat Panen dengan Pemberian Cendawan Trichoderma sp. dan Kompos.

\begin{tabular}{cccc}
\hline \multirow{2}{*}{ Perlakuan } & \multicolumn{3}{c}{ Bintil Akar } \\
\cline { 2 - 4 } & $\begin{array}{c}\text { Jumlah } \\
\text { Bintil Akar Akar Aktif }\end{array}$ & $\begin{array}{c}\text { Bintil Akar } \\
\text { Tidak Aktif }\end{array}$ \\
\hline P0: tanpa trichoderma dan kompos & $124.25^{\mathrm{a}}$ & $88.38^{\mathrm{a}}$ & $35.88^{\mathrm{ab}}$ \\
P1: 40 g trichoderma +1 kg kompos & $141.38^{\mathrm{a}}$ & $98.63^{\mathrm{a}}$ & $42.75^{\mathrm{a}}$ \\
P2: 60 g trichoderma +1 kg kompos & $126.63^{\mathrm{a}}$ & $79.50^{\mathrm{a}}$ & $47.13^{\mathrm{a}}$ \\
P3: 80 g trichoderma $+1 \mathrm{~kg}$ kompos & $144.13^{\mathrm{a}}$ & $104.38^{\mathrm{a}}$ & $39.75^{\mathrm{a}}$ \\
P4: 100 g trichoderma $+1 \mathrm{~kg}$ kompos & $111.13^{\mathrm{a}}$ & $93.00^{\mathrm{a}}$ & $18.13^{\mathrm{b}}$ \\
P5: 120 g trichoderma +1 kg kompos & $146.88^{\mathrm{a}}$ & $93.53^{\mathrm{a}}$ & $53.36^{\mathrm{a}}$ \\
\hline Rerata & 132.40 & 92.90 & 39.50 \\
$C V$ & 18.58 & 16.32 & 30.54 \\
\hline Keterangan: Nilai-nilai yang diikuti huruf yang sama menunjukkan tidak berbeda nyata
\end{tabular}
pada Uji Jarak Berganda Duncan (DMRT) taraf $5 \%$

Hal ini menggambarkan bahwa efektivitas Trichoderma dengan dosis tersebut mampu memberikan pengaruh yang baik terhadap kondisi perakaran dalam tanah. Sesuai dengan fungsinya trichoderma juga sebagai organisme pengurai bahan organik dalam tanah. Sehingga dengan terurainya bahan organik tersebut, efektivitas perakaran juga maksimal dalam membentuk bintil akar untuk menambat N2 dari udara. Ningrum (2017), menyatakan bahwa Trichoderma sp disamping sebagai organisme pengurai, dapat pula berfungsi sebagai agen hayati dan stimulator pertumbuhan tanaman. Menurut Sutanto, (2002), menyatakan bahwa trichoderma merupakan mikroba tanah yang mempunyai peran dalam kesuburan tanah, membuat hara tersedia bagi tanaman serta berperan dalam memperbaiki struktur tanah (efek tidak langsung).

Pembentukan bintil akar tanaman dapat dipengaruhi oleh kondisi perakaran, perakaran yang baik merupakan salah satu faktor penting untuk pertumbuhan tanaman. Ketersedian dan penyerapan hara/nutrisi oleh perakaran tanaman dapat berlangsung dengan baik jika kondisi perakaran tidak terganggu dengan serangan penyakit dan lainnya. Dengan penambahan trichoderma, selain dapat menjaga perakaran yang dapat menyebabkan penyakit layu pada tanaman, juga sebagai dekomposer bahan-bahan organik dari pemberian kompos. Schmidt (2006), menyatakan trichoderma merupakan jamur selulolitik yang memiliki potensi yang baik untuk mendekomposisi selulosa dan hemiselulosa dibandingkan lilin dan juga lignin. Sesuai dengan pernyataan Simanjuntak dkk, (2019) menyatakan kompos yang mengandung selulosa lebih cepa terdekomposisi dibanding yang mengandung lignin sehingga tidak baik untuk dipakai sebagai pembawa (carier) antagonis Trichoderma. Kompos yang cepat terurai maka ketersediaan nutrisi juga cepat habis sehingga tidak menunjang kehidupan mikroba dalam jangka waktu yang lama.

\subsection{Polong}

Hasil pengamatan pada beberapa komponen produksi kacang tanah, tidak terdapat perbedaan yang nyata diantara semua perlakuan pemberian trichoderma dan kompos termasuk tanaman kontrol (tanpa pemberian trichoderma dan kompos) pada semua parameter yang diamati (Tabel 2).

Tabel 2. Rata-Rata Jumlah Jumlah Polong Per Tanaman, Bobot Polong (G/Tan), Jumlah Polong Hampa, Jumlah Polong Isi, dan Jumlah Biji Per Polong Per Tanaman dengan Pemberian Cendawan Trichodermasp. dan Kompos.

$\begin{array}{llll}\text { Perlakuan } & \begin{array}{l}\text { Jumlah Bobot } \\ \text { Polong }\end{array} & \begin{array}{l}\text { Jumlah Jumlah } \\ \text { Polong } \\ \text { Hampa }\end{array} & \begin{array}{c}\text { Jumlah } \\ \text { Polong Isi }\end{array} \\ \begin{array}{c}\text { Biji/Polong/ } \\ \text { Tanaman. }\end{array}\end{array}$

\begin{tabular}{|c|c|c|c|c|c|}
\hline $\begin{array}{l}\text { P0: tanpa trichoderma dan } \\
\text { kompos }\end{array}$ & $47.88^{\mathrm{a}}$ & $73.38^{\mathrm{a}}$ & $5.63^{\mathrm{a}}$ & $42.25^{\mathrm{a}}$ & $3.42^{\mathrm{a}}$ \\
\hline $\begin{array}{l}\text { P1: } 40 \text { g trichoderma }+1 \\
\text { kg kompos }\end{array}$ & $57.00^{\mathrm{a}}$ & $100.13^{\mathrm{a}}$ & $4.88^{\mathrm{a}}$ & $52.13^{\mathrm{a}}$ & $3.45^{\mathrm{a}}$ \\
\hline $\begin{array}{l}\text { P2: } 60 \mathrm{~g} \text { trichoderma }+1 \\
\text { kg kompos }\end{array}$ & $52.75^{\mathrm{a}}$ & $84.38^{\mathrm{a}}$ & $5.13^{\mathrm{a}}$ & $48.88^{\mathrm{a}}$ & $3.43^{\mathrm{a}}$ \\
\hline $\begin{array}{l}\text { P3: } 80 \mathrm{~g} \text { trichoderma }+1 \\
\text { kg kompos }\end{array}$ & $31.00^{\mathrm{a}}$ & $47.63^{\mathrm{a}}$ & $3.88^{\mathrm{a}}$ & $30.00^{\mathrm{a}}$ & $2.90^{\mathrm{a}}$ \\
\hline $\begin{array}{l}\text { P4: } 100 \mathrm{~g} \text { trichoderma }+1 \\
\text { kg kompos }\end{array}$ & $39.00^{\mathrm{a}}$ & $62.25^{\mathrm{a}}$ & $4.00^{\mathrm{a}}$ & $37.50^{\mathrm{a}}$ & $3.41^{\mathrm{a}}$ \\
\hline $\begin{array}{l}\text { P5: } 120 \mathrm{~g} \text { trichoderma }+1 \\
\text { kg kompos }\end{array}$ & $33.25^{\mathrm{a}}$ & $50.88^{\mathrm{a}}$ & $5.38^{\mathrm{a}}$ & $31.38^{\mathrm{a}}$ & $3.08^{\mathrm{a}}$ \\
\hline Rerata & 43.48 & 69.77 & 4.81 & 40.35 & 3.28 \\
\hline $\mathrm{Cv}$ & 44.99 & 48.11 & 48.68 & 49.87 & 17.45 \\
\hline
\end{tabular}
pada Uji Jarak Berganda Duncan (DMRT) taraf $5 \%$

Berdasarkan (Tabel 2) diatas, walaupun tidak terdapat perbedaan yang nyata diantara semua perlakuan yang dicobakan terhadap semua komponen produksi yang diamati, namun dapat diketahui bahwa hasil tertinggi pada jumlah polong, bobot polong, jumlah polong isi, dan jumlah biji per polong per tanaman terdapat pada perlakuan P1 dengan dosis 40 g trichoderma $+1 \mathrm{~kg}$ kompos. Sementara jumlah polong hampa yang paling banyak justru terdapat pada pemberian dosis trichoderma yang paling tinggi yaitu perlakuan P5 (120 g trichoderma $+1 \mathrm{~kg}$ kompos). Bila dibandingkan dengan hasil pada (Tabel 1) jumlah bintil akar yang paling banyak terbentuk yaitu pada perlakuan P5. Hal ini menandakan bahwa banyaknya bintil akar yang terbentuk tidak diiringi secara langsung terhadap tingginya hasil pada beberapa komponen produksi. Diantara semua perlakuan pemberian Trichoderma dan kompos dengan dosis yang lebih tinggi dari perlakuan P1, menghasilkan komponen hasil produksi yang rendah. Hal ini diduga karena terjadi penimbunan asimilat pada daun dan organ lainnya yang tidak dapat ditranslokasikan dengan maksimal untuk pembentukan dan pengisian polong pada fase pertumbuhan generatif.

Bintil akar berperan dalam pengisian polong, yang digambarkan dalam pengamatan bobot polong. Bitil akar aktif menyumbangkan peranannya terhadap bobot polong sebesar $12,34 \%$ atau dengan nilai R2 sebesar 0,1243 dengan persamaan $\mathrm{Y}=0,0037 \mathrm{x}^{2}-1,5099 \mathrm{x}+178,12$ dengan nilai $\mathrm{R} 2=0,1243$ yang berarti bahwa jumlah bintil akar efektif sangat berpengaruh terhadap bobot polong yang dihasilkan (Gambar 1). Ini berarti sumbangan unsur hara terutama nitrogen saat pembentukan dan pengisian polong sebesar $12,43 \%$ sedangkan $87,57 \%$ lainnya dapat dijelaskan melalui penambahan trichoderma dan kompos pada media tanam. Surtiningsih et al., 2009, menyatakan terbentuknya bintil akar efektif mampu meningkatkan penambatan nitrogen yang selanjutnya untuk membentuk klorofil dan enzim. Peningkatan klorofil dan enzim mampu meningkatkan fotosintesis yang pada akhirnya dapat meningkatkan pertumbuhan vegetatif dan generatif (hasil produksi biji) tanaman.Hal lainnya yang menjadi faktor penting pertumbuhan tanaman yaitu penyerapan hara dengan baik. Penyerapan hara yang maksimal dapat mempengaruhi pertumbuhan tanaman. Cornejo, et al (2009), menyatakan bahwa serapan hara yang tinggi mempengaruhi pertumbuhan tanaman karena nutrisi tanaman terpenuhi, sehingga produksi tanaman juga semakin tinggi.

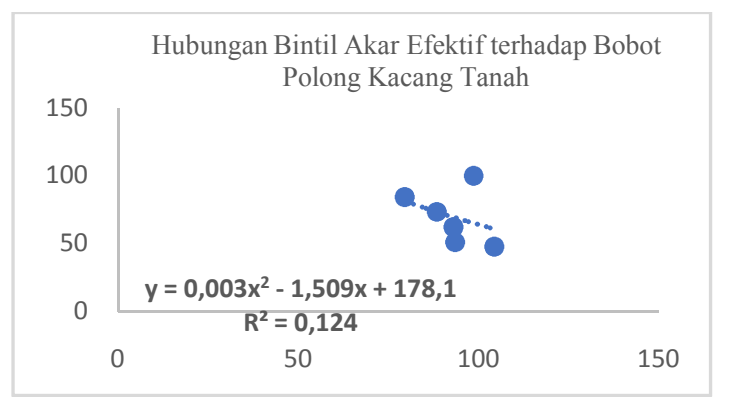

Gambar 1. Hubungan Bintil Akar Efektif terhadap Bobot Polong Kacang Tanah

Penambahan Trichoderma pada media tanam sangat berperan dalam pengisian polong, yang digambarkan dalam pengamatan bobot polong. Penambahan trichoderma menyumbangkan peranannya terhadap bobot polong sebesar $52,86 \%$ atau dengan nilai R2 sebesar 0,5286 dengan persamaan $\mathrm{Y}=$ $0,0047 \times 2+0,02803 x+79,574$ dengan nilai $R 2=0,1243$ yang berarti bahwa trichoderma sangat berpengaruh terhadap bobot polong yang dihasilkan (Gambar 2). Ini berarti sumbangan unsur hara saat pembentukan dan pengisian polong sebesar 52,86 \% sedangkan $47,14 \%$ lainnya dapat dijelaskan melalui kompos pada media tanam. Dari gambar 2 dapat dijelaskan bahwa Trichoderma yang diberikan melebihi kebutuhan tanaman kacang tanah. Tanaman kacang tanah memiliki titik optimum pemberian trichoderma yaitu berkisar antara 20 $40 \mathrm{~g}$ dalam penelitian ini. Hal yang sama juga dikatakan Siregar et al., 2018 bahwa pemberian Trichoderma dengan dosis $20 \mathrm{~g} /$ tanaman merupakan perlakuan terbaik yang menghasilkan tinggi tanaman $126,54 \mathrm{~cm}$, jumlah cabang produktif 4,13 cabang, jumlah polong per tanaman 44,10 polong, produksi per tanaman $0,81 \mathrm{~kg}$, dan produksi per plot $6,97 \mathrm{~kg}$. Penelitian sebelumnya oleh Utama et al., (2015) bahwa berat buat terong meningkat seiring dengan meningkatnya jumlah dosis trichoderma yang diberikan pada tanaman saat pengamatan berat buah minggu ke 11 .

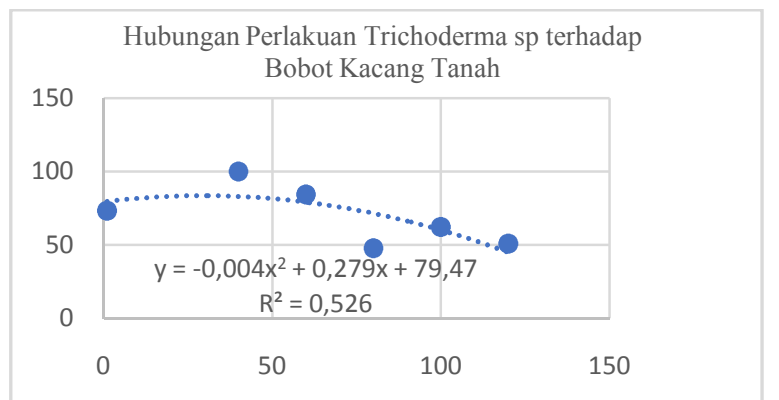

Gambar 2. Hubungan Perlakuan Trichoderma terhadap Bobot Polong Kacang Tanah

Bila dilihat dari jumlah dosis kompos yang diberikan pada semua perlakuan kecuali tanaman kontrol, semua perlakuan diberikan kompos dengan dosis yang sama sebanyak $1 \mathrm{~kg}$. Hasil yang tinggi pada perlakuan P1 diduga karena proses translokasi asimilat pada fase genaratif pembentukan dan pengisian polong terjadi secara maksimal dibandingkan perlakuan lainnya. 
Respon pertumbuhan setiap tanaman berbeda-beda bergantung pada proses penyerapan hara dan fisiologis lainnya. Pengaruh penyerapan hara dari pemberian kompos yang mengandung unsur hara seperti hara $\mathrm{P}$ dan $\mathrm{K}$, bila dimanfaatkan secara maksimal dapat membantu meningkatkan pertumbuhan dan hasil tanaman. Lingga (1995), menyatakan fosfor dapat mempercepat saat munculnya bunga karena salah satu fungsi dari fosfor dalam tanaman yaitu memacu aktivitas fotosintesis. Hasil fotosintesis dirombak melalui respirasi akan menghasilkan asimilat yang sangat dibutuhkan untuk proses pembelahan sel. Adanya peningkatan hasil fotosintesis dan jumlah asimilat maka jumlah dan ukuran sel akan mengalami peningkatan sehingga menyebabkan proses pembungaan dan pembentukan polong cepat terjadi. Kasno, (2005) menyatakan fosfor berperan dalam pembentukan sejumlah protein, membantu asimilasi, respirasi dan mempercepat pembungaan serta mempercepat proses pembentukan bunga menjadi polong.

\section{Simpulan}

Berdasarkan hasil penelitian yang dilakukan dapat disimpulkan bahwa pemberian trichoderma dan kompos tidak memberikan pengaruh yang nyata terhadap jumlah bintil akar, jumlah bintil akar yang aktif, dan komponen hasil yang diamati (jumlah polong per tanaman, bobot polong per tanaman, jumlah polong hampa, jumlah polong isi, dan jumlah biji per polong per tanaman). Namun, perbedaan yang nyata terdapat pada jumlah bintil akar yang tidak aktif diantara beberapa perlakuan pemberian cendawan trichoderma dan kompos. Hasil terbaik untuk jumlah bintil akar dengan nilai 146.88 yaitu pada perlakuan P5 (120 g trichoderma $+1 \mathrm{~kg}$ kompos). Untuk komponen produksi (jumlah polong per tanaman, bobot polong per tanaman, jumlah polong isi, dan jumlah biji per polong per tanaman) dengan hasil terbaik yaitu pada perlakuan P1 (40 g trichoderma +1 kg kompos).

\section{Pustaka}

Ardian, A. Mansyoer. 2009. Aplikasi Beberapa Dosis Tricho-kompos Untuk Meningkatkan Pertumbuhan dan Produksi Tanaman Selada (Lactuca sativa). Jurnal Online Universitas Riau. Volume 8 (2): 3540

Cornejo, C. H. A., L. Marcias Rodrigues, C.Cortes-Penagos,And J. LopezBucio. 2009. Trichoderma virens, a Plant Benefecial Fungus, Enhances Boimass Production and Promotes Lateral Root Growth Through an Auxin-Dependent Mechanism in Arabidopsis. Plant Physiol; 149 (3): 1579 - 1592

Kasno A. 2005. Profil dan perkembangan teknik produksi kacang tanah di Indonesia. Seminar Rutin Puslitbang Tanaman Pangan. Bogor (ID): Pusat Penelitian dan Pengembangan Tanaman Pangan.

Lingga, P. 1995. Petunjuk Penggunaan Pupuk. Penebar Swadaya. Jakarta

Ningrum, N.W. 2017. Manfaat mikoriza, trichoderma, beauvaria bassiana, rhizobium, bacillus sp. Direktorat jenderal tanaman pangan.Kementerianpertanian.Online:(http://tanamanpangan.pertani an.go.id/index.php/forum/main/view/683). diakses pada 17 juli 2019.

Putra Utama, Andree Saylendara, Rudi Gugum Gunawar., 2015., Pengaruh Dosis Pupuk Hayati Trichoderma sp. Terhadap Pertumbuhan dan Hasil Tanaman Terung Ungu (solanum mengolena 1.) Varietas hibrida., Jur.Agroekotek 7 (2)

Puspita F., dan T. T Nugroho. 2016. Karakterisasi Molekuler Trichokompos spp. Endofit dan Potensinya Sebagai AntiFungi Jamur Ganoderma boninense Pat. Dan Pemacu Pertumbuhan Bibit Kelapa Sawit. Laporan Tahunan Penelitian Fundamental. Universitas Riau. Pekanbaru.

Riyan Syah Siregar, Cik Zulia, Safruddin., 2018., pengaruh pemberian dosis Trichoderma sp. Dan jenis pupuk kandang terhadap pertumbuhan dan produksi tanaman kacang panjang (vigna sinensis 1)., BERNAS Agricultural Research Journal -Volume 14 No 2

Simanjuntak. GL, Assa. B, dan Manueke. J. 2019. penggunaan trichokompos untuk pengendalian penyakit layu Sclerotium rolfsii (Sacc.) curzi pada tanaman kacang tanah (Arachis hypogaea L.). Program Studi Agroteknologi, Fakultas Pertanian Universitas Sam Ratulangi Manado

Schmidt, O. 2006. Wood and Tree Fungi, Biology, damage, Protection and Use, Springe. http:// [PDF]89 Pertumbuhan Agens Hayati Trichoderma. ojs unpatti. Diakses pada tanggal 17 Juli 2019

Sinha, R.K., D. Valani, K. Chauhan, S. Agarwal. 2014. Embarking on a second green revolution for sustainable agriculture by vermiculture biotechnology using earthworms: reviving the dreams of Sir Charles Darwin. Int J Agric Health Saf. 1:50-64.

Sutanto, R. 2002. Penerapan Pertanian Organik, Pemasyarakatan dan Pengembangannya. Kanisius. Yogyakarta

T. Surtiningsih, Farida and T. Nurhariyati,"Biofertilisasi Bakteri Rhizobium Pada Tanaman Kedelai (Glycine max (L) merr.),"Berk. Penel. Hayati. no. 15, pp. 31-35. 2009.

Vassey JK. 2003. Plant Growth Promoting Rhizobacteria as Biofertilizers. Plant and Soil. 255:571-586. 